\title{
Spinal $\mu$ and $\delta$ Opioids Inhibit Both Thermal and Mechanical Pain in Rats
}

\author{
Audrey Normandin, ${ }^{1}$ Philippe Luccarini, ${ }^{4}$ Jean-Louis Molat, ${ }^{4}$ Louis Gendron, ${ }^{1,2,3}$ and Radhouane Dallel ${ }^{4}$ \\ ${ }^{1}$ Département de physiologie et biophysique, Faculté de médecine et des sciences de la santé, ${ }^{2}$ Institut de pharmacologie de Sherbrooke, and ${ }^{3}$ Centre de \\ recherche clinique Étienne-Le Bel, Université de Sherbrooke, Sherbrooke, QC J1H 5N4, Canada, and ${ }^{4}$ Clermont Université, Université d'Auvergne, NEURO- \\ DOL, BP 10448, F-63000, CLERMONT-FERRAND Inserm, U1107, F-63001 Clermont-Ferrand, France
}

The expression and contribution of $\mu$ (MOPR) and $\delta$ opioid receptors (DOPR) in polymodal nociceptors have been recently challenged. Indeed, MOPR and DOPR were shown to be expressed in distinct subpopulation of nociceptors where they inhibit pain induced by noxious heat and mechanical stimuli, respectively. In the present study, we used electrophysiological measurements to assess the effect of spinal MOPR and DOPR activation on heat-induced and mechanically induced diffuse noxious inhibitory controls (DNICs). We recorded from wide dynamic range neurons in the spinal trigeminal nucleus of anesthetized rats. Trains of 105 electrical shocks were delivered to the excitatory cutaneous receptive field. DNICs were triggered either by immersion of the hindpaw in $49^{\circ} \mathrm{C}$ water or application of $300 \mathrm{~g}$ of mechanical pressure. To study the involvement of peptidergic primary afferents in the activation of DNIC by noxious heat and mechanical stimulations, substance $P$ release was measured in the spinal cord by visualizing neurokinin type 1 receptor internalization. We found that the activation of spinal MOPR and DOPR similarly attenuates the DNIC and neurokinin type 1 receptor internalization induced either by heat or mechanical stimuli. Our results therefore reveal that the activation of spinal MOPR and DOPR relieves both heat-induced and mechanically induced pain with similar potency and suggest that these receptors are expressed on polymodal, substance P-expressing neurons.

\section{Introduction}

In peripheral tissues, noxious mechanical, thermal, and chemical stimuli are detected by nociceptors and converted to action potentials by lightly myelinated $\mathrm{A} \delta$ and nonmyelinated C-fibers (Julius and Basbaum, 2001; Stein and Lang, 2009). Unlike other sensory receptors, most nociceptors are thought to be polymodal (Perl, 1996; Cain et al., 2001) (i.e., sensitive to both heat and mechanical noxious stimuli) (Julius and Basbaum, 2001). Until recently, discrimination between different pain modalities was therefore considered to happen primarily at spinal and/or supraspinal sites (Perl, 2007). Indeed, recent findings revealed that

Received April 17, 2013; revised June 4, 2013; accepted June 7, 2013.

Author contributions: A.N., P.L., J.-L.M., L.G., and R.D. designed research; A.N., P.L., and J.-L.M. performed research; A.N., P.L., J.-L.M., L.G., and R.D. analyzed data; A.N., P.L., J.-L.M., L.G., and R.D. wrote the paper.

This work was supported by the Natural Sciences and Engineering Research Council of Canada and the Canadian Institutes of Health Research grants to L.G. and a Laboratory exchange program opportunity grant from the Fonds de Recherche Québec-Santé (FRQ-S)-funded Quebec Pain Research Network to L.G. and R.D. L.G. is the recipient of a FRQ-S Junior 2 salary support. A.N. was the recipient of the Frederick Banting and Charles Best Canada Graduate Scholarships-Master's Award awarded by the Canadian Institutes of Health Research and a Master scholarship from the FRQ-S. This work was also supported by the Institut National de la Santé et de la Recherche Médicale, Université d'Auvergne-Clermont 1 (France) and Région Auvergne. We thank Hélène Beaudry for technical assistance and Robert Dumaine and Philippe Sarret (Université de Sherbrooke) for granting access to the Olympus confocal microscope funded by the Canadian Foundation for Innovation.

The authors declare no competing financial interests.

Correspondence should be addressed to either of the following: Dr. Louis Gendron, Département de physiologie et biophysique, Université de Sherbrooke, Faculté de médecine et des sciences de la santé, 3001 12th Avenue North, Sherbrooke, QC J1H 5N4, Canada, E-mail: Louis.Gendron@USherbrooke.ca; or Pr. Radhouane Dallel, INSERM UMR 1107, Neuro-Dol, Douleur Trigéminale et Migraine, Faculté de Chirurgie Dentaire, 11 boulevard Charles de Gaulle, 63000 Clermont-Ferrand, France, E-mail: Radhouane.dallel@udamail.fr.

DOI:10.1523/JNEUROSCI.1631-13.2013

Copyright $\odot 2013$ the authors $\quad 0270-6474 / 13 / 3311703-12 \$ 15.00 / 0$ noxious stimuli of various natures specifically activate different neuronal pathways and, consequently, that the distinction between pain modalities would instead occur at the level of primary afferents (Abrahamsen et al., 2008; Cavanaugh et al., 2009; Scherrer et al., 2009). In particular, this model suggests that heat and mechanical sensitivity are processed by distinct subpopulations of primary afferent fibers. Indeed, in mice, a subpopulation of lightly myelinated A $\delta$ fibers (Koltzenburg et al., 1997; Cain et al., 2001) and nonpeptidergic unmyelinated IB4-positive C-fibers (Cavanaugh et al., 2009; Scherrer et al., 2009) were shown to be specific mechanosensitive nociceptors. By contrast, peptidergic IB4-negative C-fibers expressing substance $\mathrm{P}$ and calcitonin gene-related peptide preferentially mediate heat sensitivity ( $\mathrm{Ca}-$ vanaugh et al., 2009; Scherrer et al., 2009).

Adding to the controversy, Scherrer et al. (2009) had recently reported that, in mice, the $\delta$ opioid receptors (DOPRs) were absent from peptidergic nociceptors expressing $\mu$ opioid receptors (MOPRs). In support of a role of primary afferents in the discrimination of pain modalities, they further showed that activation of spinal DOPR preferentially inhibits mechanical pain, whereas activation of spinal MOPR preferentially inhibits thermal pain (Scherrer et al., 2009). However, numerous studies have shown that the selective activation of MOPR with [D-Ala ${ }^{2}$, $\mathrm{N}-\mathrm{Me}-\mathrm{Phe}^{4}, \mathrm{Gly}^{5}$-ol]-enkephalin (DAMGO) injected at the level of the spinal cord can efficiently alleviate both heat-induced (Porreca et al., 1984; Malmberg and Yaksh, 1992; Nagasaka and Yaksh, 1995; Kondo et al., 2005; Scherrer et al., 2009; van Rijn et al., 2012) and mechanically induced pain (Nichols et al., 1995; Sluka et al., 2002; Kondo et al., 2005; Chen and Pan, 2006; van 
Rijn et al., 2012). Similarly, the activation of spinal DOPR was shown to relieve heat (Stewart and Hammond, 1994; Tseng et al., 1997; Qiu et al., 2000; Cahill et al., 2001, 2003; Morinville et al., 2003; Gendron et al., 2007a,b; Beaudry et al., 2009; Overland et al., 2009; Dubois and Gendron, 2010) and mechanical pain (Miaskowski et al., 1990, 1991; Sutters et al., 1990; Holdridge and Cahill, 2007; Scherrer et al., 2009; Otis et al., 2011). Therefore, a more thorough investigation of the role of spinal MOPR and DOPR and their ability to inhibit various pain modalities is required.

In the present study, we investigated whether spinal MOPR and DOPR differentially regulate thermal and mechanical pain by assessing the effects of intrathecal DAMGO and deltorphin II on both diffuse noxious inhibitory controls (DNICs) and spinal neurokinin type $1\left(\mathrm{NK}_{1}\right)$ receptor internalization triggered by thermal and mechanical noxious stimulations of the rat hindpaws.

\section{Materials and Methods Animals}

Studies in rats. Adult male Sprague Dawley rats weighting 250-300 g (from Charles River Laboratories) were maintained on a $12 \mathrm{~h}$ light/dark cycle. Laboratory food and water were available ad libitum. Experiments were approved by the animal care committees at the Universite d'AuvergneClermont 1 (Comité d'Éthique en Matière d'Expérimentation Animale Auvergne CE 26-12) and the Université de Sherbrooke (protocol 242-10). All procedures were in compliance with the policies and directives of the Canadian Council on Animal Care and guidelines from both the International Association for the Study of Pain and the Directives of the European Parliament and the Council on the protection of animals used for scientific purposes (Dir.2010/63/UE).

Studies in mice. Adult male C57BL/6 mice (20-25 g: Charles River Laboratories) were housed in groups of four and maintained on a $12 \mathrm{~h}$ light/dark cycle. Laboratory food and water were available ad libitum. Experiments were approved by the animal care committee at the Université de Sherbrooke (protocol 242-10). All procedures were in compliance with the policies and directives of the Canadian Council on Animal Care and guidelines from the International Association for the Study of Pain. The experiments were designed to minimize the number of animals used and their suffering.

\section{Drugs}

DAMGO-enkephalin acetate salt (Tocris Bioscience, batch 22; and Sigma-Aldrich, lot BCBB7749), a MOPR-selective agonist, and deltorphin II (Dlt II) (American Peptide, lot M08048T1; and Sigma-Aldrich, lot 079K8741), a DOPR-selective agonist, were dissolved in saline solution $(0.9 \% \mathrm{NaCl})$. The drugs were injected intrathecally either by lumbar catheterization for electrophysiological studies $(5 \mu \mathrm{g}$ of DAMGO in a volume of $10 \mu \mathrm{l}$; corresponding to $9.7 \mathrm{nmol}$ and $8 \mu \mathrm{g}$ of Dlt II in a volume of $10 \mu \mathrm{l}$; corresponding to $10.2 \mathrm{nmol}$ ) or lumbar puncture for $\mathrm{NK}_{1}$ receptor internalization studies ( $5 \mu \mathrm{g}$ of DAMGO in a volume of $30 \mu \mathrm{l}$ and $10 \mu \mathrm{g}$ of Dlt II in a volume of $30 \mu \mathrm{l}$; corresponding to $12.7 \mathrm{nmol}$ ). To ascertain drug specificity and selectivity, respectively, for MOPR and DOPR, in the electrophysiological studies, naloxone $0.4 \mathrm{mg} / \mathrm{kg}$ intravenously, a nonselective opioid antagonist, and naltrindole $4 \mathrm{mg} / \mathrm{kg}$ intravenously, a DOPR-selective antagonist, were injected via the jugular vein. Selectivity of DAMGO and Dlt II in the $\mathrm{NK}_{1}$ receptor internalization studies was demonstrated in a previous study (Beaudry et al., 2011).

\section{Electrophysiological recordings}

Animal preparation

As previously described (Lapirot et al., 2011), the rats were anesthetized with $2 \%$ halothane in a $\mathrm{NO}_{2} / \mathrm{O}_{2}$ mixture (2:1). After intramuscular injection of $100 \mu \mathrm{g}$ atropine sulfate, the trachea was cannulated. The carotid artery and external jugular vein were catheterized. The animals were then paralyzed by intravenous perfusions of vecuronium bromide $(2.4 \mathrm{mg} / \mathrm{h})$ and artificially ventilated with volume-controlled pumps
(54-55 strokes/min). The levels of $\mathrm{O}_{2}, \mathrm{~N}_{2} \mathrm{O}$, and end-tidal $\mathrm{CO}_{2}(3.5-$ $4.5 \%$ ) were monitored by an anesthetic gas analyzer (Dräger Vamos) during the entire experimental period. These parameters were digitally displayed and under the control of alarms. The arterial catheter was attached to a calibrated pressure transducer (UFI) connected to an amplifier (Stoelting) for continuous monitoring of the mean arterial blood pressure (90-110 $\mathrm{mmHg}$ ). The analog output from the blood pressure amplifier was connected to a computer data sampling system (Cambridge Electronics Design 1401 computer interface). The heart rate was continuously monitored, and cutaneous vascularization was periodically checked by observing the color of the paw extremities and the rapidity by which they regained normal color after pressure application. The colorectal temperature was kept constant at $38 \pm 0.5^{\circ} \mathrm{C}$ with a feedbackcontrolled heating blanket. The surgical level of anesthesia was verified by a stable mean arterial blood pressure and a constant heart rate during noxious stimulation.

The animals were placed in a stereotaxic frame with the head fixed in a ventroflexed position (incisor bar dropped $5 \mathrm{~mm}$ under the standard position) by means of an adapted metallic bar. For spinal trigeminal subnucleus oralis $(\mathrm{Sp} 5 \mathrm{O})$ recordings, a craniotomy was performed on the right side at the level of the occipitoparietal suture, and the dura mater was removed.

For the lumbar catheterization, a $2 \mathrm{~cm}$ longitudinal skin incision was made directly over the L5-L6 lumbar vertebrae. The subcutaneous soft tissue was eliminated, and the skin incision was drawn to the dorsal midline. The paravertebral muscles were separated to expose the L5 and L6 vertebrae. A curved Friedman-Pearson rongeur (F.S.T.) was used to break the spinal crest of the L6 vertebrae and then expose the dura. We cut a rat intrathecal polyurethane short catheter (Alzet, Durect) into 4.5 -cm-long $28 \mathrm{G}$ tubing. A Teflon-coated, stainless steel stylet guided the catheter into the subarachnoid space from the lumbar spinal column (L5-L6) to the thoracic spinal column (T12-T13). DAMGO (5 $\mu \mathrm{g})$ or Dlt II $(8 \mu \mathrm{g})$ was injected via this catheter over a period of $2 \mathrm{~s}$. Appropriate placement of the catheter was verified by dissecting the animals at the end of the experiment. After the surgery, the level of halothane was reduced to $0.6-0.7 \%$ and maintained during the entire recording period.

\section{Recordings}

Unitary extracellular recordings were made from the right $\mathrm{Sp} 5 \mathrm{O}$ with glass micropipettes (7-10 M $\Omega$ ) filled with a mixture of $5 \% \mathrm{NaCl}$ and pontamine sky blue. The brainstem was explored $2.4-3.0 \mathrm{~mm}$ laterally to the midline and between the frontal planes AP -1.1 and AP $-2.6 \mathrm{~mm}$ from the interaural line (Paxinos and Watson, 1997). Single-unit activities were amplified and displayed on oscilloscopes. The activities went into a window discriminator connected to a CED 1401plus interface (Cambridge Electronic Design) and a PC computer (Spike 2.06 software), which allowed sampling and analysis of the spontaneous and evoked neuronal activity. Wide-dynamic range (WDR) neurons were recognized based on their responses to mechanical non-noxious (brushing with a soft brush) and noxious (pinch with forceps) stimulations of their receptive fields as previously described (Dallel et al., 1999). Specifically, each neuron that responded in a graded manner with increasing firing rates to the stimulus range from non-noxious to noxious intensity was classified as a WDR cell. Once a neuron was identified, electrical square-wave stimuli ( $2 \mathrm{~ms}$ duration) were applied through a pair of stainless steel needle electrodes subcutaneously placed into the center of the receptive field; the thresholds for eliciting A- and C-fiber-evoked responses were determined. In poststimulus time histograms (PSTHs), A- and C-fiber-evoked responses were distinguished by their latencies, but only C-fiber-evoked responses were considered in the detailed analysis. Previous research showed that burst discharges at latencies $>30 \mathrm{~ms}$ are elicited by C-fibers (Hu, 1990; Dallel et al., 1999). Therefore, all spikes occurring between 30 and $200 \mathrm{~ms}$ after a stimulus were considered to be C-fiber-evoked.

\section{Experimental design}

Sequences of 105 electrical stimuli $(0.66 \mathrm{~Hz})$ were applied to the receptive field at 3 times the threshold for C-fiber activation every $10 \mathrm{~min}$. DNICs 
were triggered by alternatively immersing one hindpaw into a $49^{\circ} \mathrm{C}$ water bath or applying a mechanical pressure of $300 \mathrm{~g}$ to the other hindpaw with calibrated forceps between the 36th and 60th stimuli (i.e., for $37.5 \mathrm{~s}$ ) (see Fig. 1A). The pressure of $300 \mathrm{~g}$ was determined from pilot electrophysiological experiments, which showed that this was the minimal pressure required to induce a reduction of at least $40 \%$ of C-fiber-evoked action potentials. This pressure is also in the range of the pressures reached in the Randall-Selitto's test in which $400 \mathrm{~g}$ (Chen and Pan, 2006; Sibilia et al., 2012) or higher pressures (Miaskowski et al., 1991; Muthuraman and Singh, 2011) are commonly used as a cutoff. Only one hindpaw at a time received a noxious stimulation, and the order of application of the noxious stimulation was alternated for each animal. For example, for one animal, we began with the thermal stimulus and then proceeded with the mechanical stimulus. For another animal, we instead began with mechanical stimulation, followed with thermal stimulation and so forth. Thus, when all the tested animals were considered, the effects of $5 \mu \mathrm{g}$ DAMGO or $8 \mu \mathrm{g}$ Dlt II on both heat-induced and mechanically induced DNICs were tested 10, 20, 30, and 40 min after the administration of the opioid. To ascertain the drug specificity in the observed effects, naloxone $(0.4 \mathrm{mg} / \mathrm{kg}$ intravenously), a nonselective opioid receptor antagonist, was injected $50 \mathrm{~min}$ after the administration of DAMGO in animals. For the Dlt II-injected rats, naltrindole $(4 \mathrm{mg} / \mathrm{kg}$ intravenously), a DOPR-selective antagonist, was used.

The analyses were performed as previously described (Lapirot et al., 2011). Briefly, in each sequence, the PSTHs determined from the 21 st to 35 th responses were used for studying the unconditioned response (before noxious stimulation; control period), and those derived from responses 36th to 105th were used for studying the DNICs. To assess the inhibitory effect of noxious heat or a mechanical stimulus, only the 46th60 th responses were considered because responses induced between the 36 th -45 th noxious stimuli correspond to the time required (5-10 s) to reach the maximal inhibitory effects. In each sequence, PSTHs derived from the 46th-60th (DNIC effect) were normalized to PSTHs derived from the 21st to 35th responses (unconditioned response; control period). The inhibitory effect of the DNIC was computed as the percentage decrease in the number of C-fiber-evoked action potentials.

DAMGO $(5 \mu \mathrm{g}$ in $10 \mu \mathrm{l})$ or Dlt II $(8 \mu \mathrm{g}$ in $10 \mu \mathrm{l})$ was intrathecally injected after two stable control sequences were recorded (i.e., variation in unconditioned $\mathrm{C}$-fiber response $<10 \%$ ). Each rat received only one injection of DAMGO or Dlt II.

\section{$\mathrm{NK}_{1}$ receptor internalization \\ Animal perfusion}

Studies in rats. The animals were deeply anesthetized in an induction cage with $5 \%$ isoflurane- $95 \%$ medical air mixture (the anesthetic used in Sherbrooke) and maintained during the entire procedure with $2 \%$ of the same anesthetic distributed via a mask. In those experiments, DAMGO $(5 \mu \mathrm{g}$ in $30 \mu \mathrm{l})$, Dlt II $(10 \mu \mathrm{g}$ in $30 \mu \mathrm{l})$, or saline was administered via direct lumbar puncture using a technique with a high success rate that was previously described by others (Fairbanks, 2003) and extensively used in our laboratory (Beaudry et al., 2009, 2011; Otis et al., 2011). Briefly, a 30-gauge 0.5 -inch needle mounted on a Luer tip Hamilton syringe (VWR) was inserted into the L5-L6 intervertebral space of the anesthetized animal (at the level of the cauda equina), and the injection was performed over a period of $2 \mathrm{~s}$. Appropriate placement of the needle was confirmed by observing a brief twitch of the tail. DAMGO, Dlt II, or saline was intrathecally injected $10 \mathrm{~min}$ before application of either heat stimulation at $49^{\circ} \mathrm{C}$ or a mechanical pressure of $300 \mathrm{~g}$ for $38 \mathrm{~s}$ on the right hindpaw. As previously described (Beaudry et al., 2011), 10 min after the noxious stimulation (i.e., 20 min after DAMGO, Dlt II, or saline injection), the animals were perfused through the aortic arch with $500 \mathrm{ml}$ of $4 \%$ PFA and $0.18 \%$ picric acid in $0.1 \mathrm{M}$ phosphate buffer with $\mathrm{pH} 7.4$ at $4^{\circ} \mathrm{C}$. The spinal cord was then removed, postfixed in the same solution for $1 \mathrm{~h}$, and cryoprotected for $48 \mathrm{~h}$ in a solution of $30 \%$ sucrose in $0.2 \mathrm{M}$ phosphate buffer. The lumbar segment of the spinal cord was snap frozen in isopentane at $-45^{\circ} \mathrm{C}$ and stored at $-80^{\circ} \mathrm{C}$ until sectioning. The lumbar segments of the spinal cord were sliced in transverse sections ( $30 \mu \mathrm{m}$ thick) on a frozen microtome, and immunolabeling of $\mathrm{NK}_{1}$ receptors was performed on free-floating sections. Briefly, the slices were incubated for
$30 \mathrm{~min}$ at room temperature in $1 \%$ sodium borohydride diluted in PBS to quench aldehyde-induced fluorescence present in tissues and thoroughly rinsed. The sections were incubated overnight at $4^{\circ} \mathrm{C}$ in a rabbit anti- $\mathrm{NK}_{1}$ receptor polyclonal antibody (directed against the C-terminal of $\mathrm{NK}_{1}$ receptors of rat origin, amino acids 393-407; Sigma-Aldrich) diluted 1:5000 in a solution containing 3\% normal goat serum and $0.3 \%$ Triton X-100 in PBS. The slices were washed in PBS and then incubated with a fluorescent goat anti-rabbit secondary antibody (Alexa-488, Invitrogen) diluted 1:1000 in PBS for $1 \mathrm{~h}$ at room temperature.

Studies in mice. Mice were deeply anesthetized as described for rats. They then received a noxious heat (immersion in a $49^{\circ} \mathrm{C}$ water bath) or mechanical (application of a $200 \mathrm{~g}$ pressure) stimulation for $38 \mathrm{~s}$ on their right hindpaw. Ten minutes after mice had received the noxious stimulation, they were intracardially perfused with $30 \mathrm{ml}$ of $4 \%$ PFA and $0.18 \%$ picric acid in $0.1 \mathrm{M}$ phosphate buffer with $\mathrm{pH} 7.4$ at $4^{\circ} \mathrm{C}$. The spinal cord was then removed, postfixed in the same solution for $2 \mathrm{~h}$, and cryoprotected for $48 \mathrm{~h}$ in a solution of $30 \%$ sucrose in $0.2 \mathrm{~m}$ phosphate buffer. The lumbar segment (L4-L6) of the spinal cord was snap frozen in isopentane at $-45^{\circ} \mathrm{C}$ and stored at $-80^{\circ} \mathrm{C}$ until sectioning. The dorsal part of the L4-L6 spinal cord segment was cut on a cryostat into 8-10 serial $20-\mu \mathrm{m}$-thick horizontal sections to examine superficial laminae I-II. Horizontal sections were directly mounted on HistoBond adhesive microscope slides (VWR), and immunohistochemistry was performed directly on the slides. Briefly, the slices were thawed at room temperature before rehydration for $10 \mathrm{~min}$ in PBS. They were then incubated for $30 \mathrm{~min}$ at room temperature in $0.1 \mathrm{~m}$ glycine diluted in PBS to quench aldehyde-induced fluorescence present in tissues and rinsed. The sections were incubated overnight at $4^{\circ} \mathrm{C}$, in a humid container, with the anti-NK $\mathrm{NK}_{1}$ receptor polyclonal antibody (1:5000) solution described above. The slices were washed in PBS and then incubated with the fluorescent secondary antibody (1:1000) solution for $1 \mathrm{~h}$ at room temperature.

The proportion of spinal cord neurons exhibiting internalized $\mathrm{NK}_{1}$ receptors was quantified by a previously described method (Abbadie et al., 1997; Marvizon et al., 2003; Kondo et al., 2005; Nazarian et al., 2008; Beaudry et al., 2011). Briefly, we used an epifluorescence microscope (Leica DM4000B; Leica Microsystem) to count $\mathrm{NK}_{1}$ receptor-like immunoreactive cell bodies. Neurons with and without $\mathrm{NK}_{1}$ receptor internalization located in the superficial lamina I were counted, and the percentage of $\mathrm{NK}_{1}$ receptor immunoreactive cells with internalization was calculated. The number of neurons with $\mathrm{NK}_{1}$ receptor internalization was determined by averaging the counts made in 3-5 rats per condition (14-18 sections per animal) or 4 or 5 mice per condition (3-6 sections per animal). During the counting procedure, the observer was unaware of the treatment received by the animals. A neuron was considered having internalized $\mathrm{NK}_{1}$ receptors if the membrane was barely labeled and if $>50$ vesicle-like fluorescent puncta were observed in the cell body. The results were expressed as the mean \pm SEM.

For the purpose of illustrating our observations, representative confocal images were collected with the Olympus Fluoview 1000 (FV1000) laser-scanning confocal microscope fitted with an U Plan S-Apo 60X (1.35 NA) oil-immersion objective.

\section{Calculations and statistical analysis}

The calculations were performed with Excel 2007 (Microsoft), graphs were created with SigmaPlot 11.0, and statistical analyses were performed with Prism GraphPad 5.0. The data are expressed as the mean \pm SEM. $p$ values are presented in the figure legends.

\section{Results}

\section{Characteristics of trigeminal WDR neurons}

Seventeen WDR neurons were recorded within the Sp5O to test the effect of DAMGO $(n=8)$ and Dlt II $(n=9)$ on noxious heat and mechanical stimulations. None of the neurons exhibited spontaneous activity. All of them had ipsilateral receptive fields that included the intraoral or perioral region. They were sensitive to both innocuous and noxious mechanical stimuli and responded by increasing their firing rates as the stimulus intensity 
increased into the noxious range. When 2-ms-long percutaneous electrical stimuli were applied to the center of the receptive fields of the neurons, responses attributable to peripheral activation of A- and C-fibers could be observed (data not shown). The longest latency responses (89 $\pm 3.7 \mathrm{~ms}, n=17)$ were C-fiberevoked. Indeed, the computed conduction velocity $(\sim 0.5 \mathrm{~m} / \mathrm{s})$ was in the range of those previously reported for C-fibers (Hu, 1990; Dallel et al., 1999; Coste et al., 2008a,b; Lapirot et al., 2011). In addition, long latency responses could only be evoked by high intensity stimulations (mean threshold, $10.3 \pm 0.8 \mathrm{~mA}, n=17$ ), and they exhibited windup. Figure $1 A$ illustrates the experimental design used for the electrophysiological assays. As shown in Figure 1 (examples), immersion of the hindpaw in a $49^{\circ} \mathrm{C}$ water bath (Fig. $1 B$ ) or application of a $300 \mathrm{~g}$ pressure (Fig. 1C) between the 36th and 60th electrical stimulus induced a strong inhibition of C-fiber-evoked firing of Sp5O WDR neurons. This inhibition reflects the activation of DNICs.

The effects of intrathecal DAMGO and Dlt II injection on the DNIC induced by a noxious heat stimulus

All tested neurons were under the influence of the DNICs. The C-fiber-evoked responses of all those neurons were strongly depressed by the application of noxious heat stimulation $\left(49^{\circ} \mathrm{C}\right)$ to one of the hindpaws (Fig. $2 \mathrm{~A}, \mathrm{E}$, examples).

Regarding the experiments with DAMGO $(n=8)$, quantitative analysis showed that noxious heat stimulation induced a mean inhibition of $89 \pm 4 \%$ before the injection of the drug. The intrathecal injection of DAMGO $(5 \mu \mathrm{g})$ alone (i.e., without the heterotopic conditioning stimulus) has no effect on the C-fiberevoked responses of trigeminal WDR neurons (Fig. 2B; see also Fig. $4 B$, between the first and the 36th electrical stimuli), but the injection strongly reduced the inhibitory effect induced by noxious heat stimulation of the hindpaw (Fig. 2B). Ten to 20 and $30-40$ minutes after the administration of DAMGO, the inhibitions of C-fiber-evoked responses during heat application were $33 \pm 7 \%$ and $32 \pm 8 \%$, respectively (Fig. $2 D$ ). Indeed, spinally administered DAMGO induced reductions of $62 \pm 8 \%$ and $65 \pm$ $9 \%$ of the DNICs $(p<0.0001, F=20.30$, one-way ANOVA for repeated measures followed by Bonferroni's multiplecomparison test). The specificity of the effects of intrathecally administered DAMGO upon the DNIC was tested by administering the opiate antagonist naloxone. For all the tested neurons, systemic administration of naloxone (intravenous injection, 0.4 $\mathrm{mg} / \mathrm{kg}$ ) antagonized the effect of DAMGO, indicating that it was opioid receptor-mediated (Fig. 2C,D). Immersion of one of the hindpaw of the rats in the water bath reduced by $87 \pm 5 \%$ the C-fiber-evoked action potentials of Sp5O WDR neurons. As for DAMGO, the intrathecal injection of Dlt II $(8 \mu \mathrm{g})$ alone (i.e., without the heterotopic conditioning stimulus) has no effect on the C-fiber-evoked responses of trigeminal WDR neurons (Fig. $2 F$; see also Fig. $4 F$, between the first and the 36th electrical stim- uli), but the injection strongly reduced the inhibitory effect induced by noxious heat stimulation of one hindpaw (Fig. $2 F$ ). Ten to 20 and 30-40 minutes after the administration of Dlt II, the inhibitions of C-fiber-evoked responses during heat application were $36 \pm 8 \%$ and $55 \pm 8 \%$, respectively (Fig. $2 H$ ). Indeed, spinally administered Dlt II induced reductions of $56 \pm 11 \%$ and $38 \pm 8 \%$ of the DNICs $(p<0.0001, F=13.81$, one-way ANOVA for repeated measures followed by Bonferroni's multiplecomparison test). The selectivity of the effects of intrathecally administered Dlt II upon the heat-induced DNIC was tested by administering the DOPR-selective antagonist naltrindole. For all the tested neurons, systemic administration of naltrindole (intravenous injection, $4 \mathrm{mg} / \mathrm{kg}$ ) antagonized the effect of Dlt II, indicating that it was DOPR-mediated (Fig. 2G,H).

In an interesting way, the effects of spinally administered DAMGO and Dlt II (at equimolar doses), when compared together, show no significant difference in their ability to reduce the activation of heat-induced DNICs ( $p=0.1451, F=2.36$, twoway ANOVA for repeated measures followed by Bonferroni's multiple-comparison test).

\section{The effects of intrathecal DAMGO and Dlt II injection on} heat-induced $\mathrm{NK}_{1}$ receptor internalization

A well-known phenomenon is that, after the activation of peptidergic primary afferent fibers by noxious stimulation, substance $\mathrm{P}$ is released in the superficial laminae of the spinal cord, where it binds to and activates $\mathrm{NK}_{1}$ receptors. Upon activation, $\mathrm{NK}_{1}$ receptors are rapidly internalized (Mantyh et al., 1995; Abbadie et al., 1997; Marvizon et al., 2003; Nazarian et al., 2008; Beaudry et 

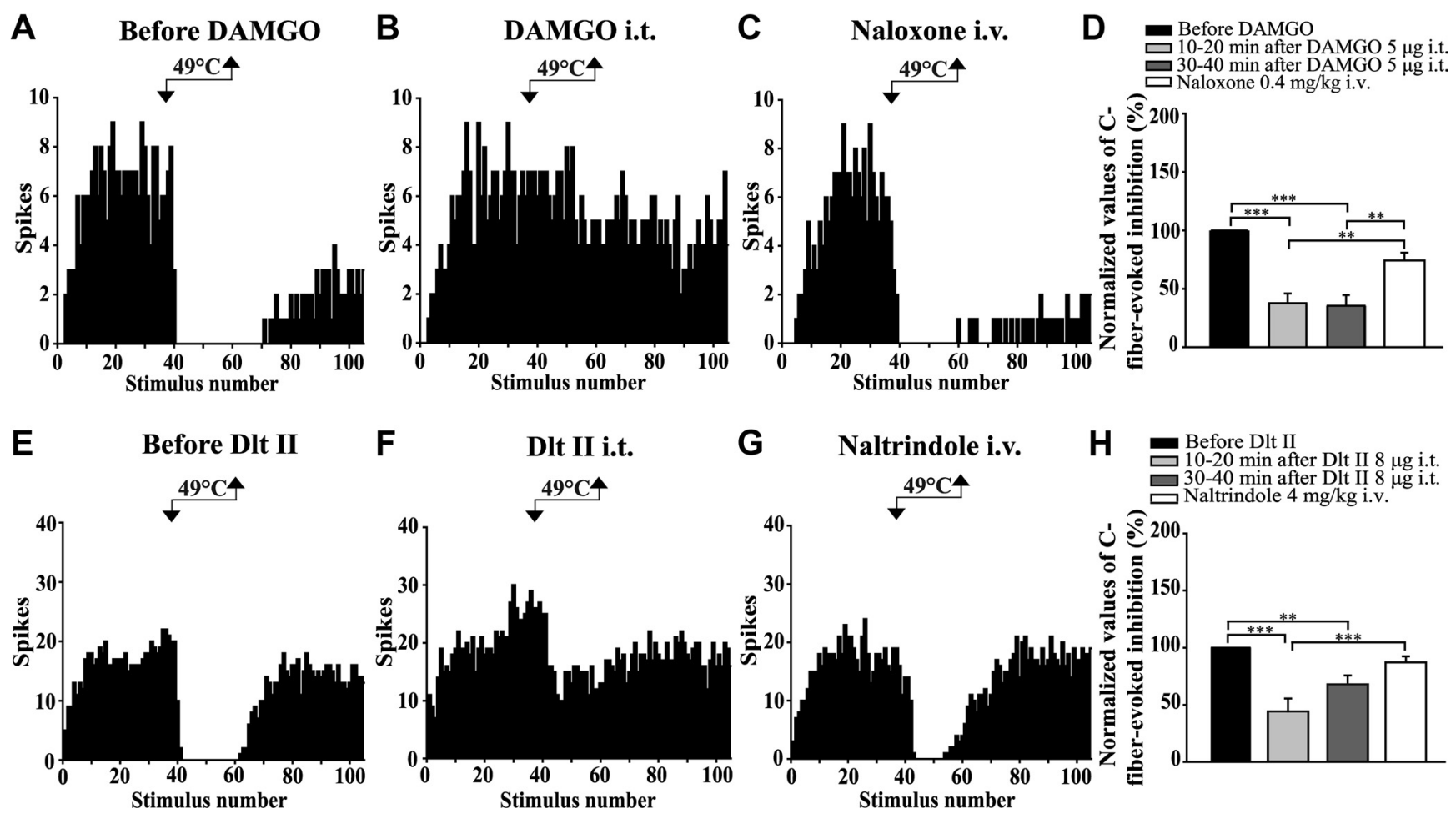
Naloxone $0.4 \mathrm{mg} / \mathrm{kg}$ i.v.

Figure 2. Intrathecal DAMGO and DIt II both inhibit the DNIC induced by a noxious heat stimulus. $\boldsymbol{A}-\boldsymbol{C}, \boldsymbol{E}-\mathbf{G}$, Histograms showing representative $C$-fiber-evoked responses of two trigeminal WDR neurons to 105 successive electrical stimulations recorded before $(\boldsymbol{A}, \boldsymbol{E})$ and $10 \mathrm{~min}$ after intrathecal (i.t.) administration of DAMG0 $5 \mu \mathrm{g}(\boldsymbol{B})$ or $20 \mathrm{~min}$ after Dlt II $8 \mu \mathrm{g}(\boldsymbol{F})$. Between the 36 th and 60 th stimulation, one hindpaw was immersed into a $49^{\circ} \mathrm{C}$ water bath. The DNICs triggered by heat noxious stimulation of the hindpaw are reduced after both DAMGO $(\boldsymbol{B})$ and DIt II $(\boldsymbol{F})$ injection. The intravenous (i.v.) administration of naloxone $(\boldsymbol{C})$ and naltrindole $(\boldsymbol{G})$ reversed the effect of DAMGO and Dlt II, respectively. $\boldsymbol{D}, \boldsymbol{H}$, Graphic representation showing the mean $(n=8$ for $\boldsymbol{D}$, and $n=9$ for $\boldsymbol{H}$ ) percentage of inhibition of C-fiber-evoked action potentials before and $10-20 \mathrm{~min}$ and $30-40$ min after the intrathecal injection of the opioids. The data are individually normalized to those before administration of the opioids. The selective MOPR and DOPR agonists significantly reduced the percentage of inhibition of C-fiber-evoked action potentials either $10-20$ or $30-40$ min after their administration. Naloxone significantly reversed those opioidergic-induced effects, and naltrindole significantly reversed the D0PR-mediated effect $10-20$ min after Dlt II administration. ${ }^{* *} p<0.01$ (one-way ANOVA for repeated measures with Bonferroni's post hoc test). ${ }^{* *} p<0.001$ (one-way ANOVA for repeated measures with Bonferroni's post hoc test). Error bars indicate the SEM.

al., 2011). $\mathrm{NK}_{1}$ receptor internalization can therefore be used as an indication of the activation of peptidergic primary afferent fibers.

In the ipsilateral side of control rats, immunostaining of $\mathrm{NK}_{1}$ receptors in the rat spinal cord revealed intense immunofluorescent labeling located mainly at the cell surface of laminae I of the lumbar spinal cord (Fig. 3E; see Fig. 5E, first column; $15 \pm 2 \%$ of lamina I neurons have internalized $\mathrm{NK}_{1}$ receptors). In animals pretreated with intrathecal saline, noxious heat stimulation (immersion of the right hindpaw in $49^{\circ} \mathrm{C}$ water bath during $38 \mathrm{~s}$ ) induced $\mathrm{NK}_{1}$ receptor internalization in the majority of the lamina I neurons of the ipsilateral lumbar spinal cord (Fig. 3 B, E; $72 \pm 4 \%$ of laminae I neurons have internalized $\mathrm{NK}_{1}$ receptors). In contrast, only discrete $\mathrm{NK}_{1}$ receptor internalization was observed in the contralateral side of the spinal cord (Fig. 3A). Intrathecal DAMGO (Fig. 3C) and Dlt II (Fig. 3D) administered 10 min before noxious heat stimulation significantly decreased the proportion of neurons with internalized $\mathrm{NK}_{1}$ receptors to $37 \pm 4 \%$ and $52 \pm 3 \%$, respectively (Fig. 3E). Those results correspond to a reduction of $\sim 49 \%$ for DAMGO and $28 \%$ for Dlt II, of laminae I neurons with internalized $\mathrm{NK}_{1}$ receptors. We found no significant difference between the effects of DAMGO and Dlt II on their ability to inhibit heat-induced $\mathrm{NK}_{1}$ receptor internalization (Fig. 3E) $(p<0.0001, F=4.03$, one-way ANOVA followed by Bonferroni's multiple-comparison test).
The effects of intrathecal DAMGO and Dlt II injection on the DNIC induced by a noxious mechanical stimulus

C-fiber-evoked responses were strongly depressed by the application of noxious mechanical ( $300 \mathrm{~g}$ ) stimulation to the hindpaw (Fig. 4A,E, examples). For assays where DAMGO was tested, quantitative analysis showed a mean inhibition of $56 \pm 8 \%$ of C-fiber-evoked firing of $\mathrm{Sp} 5 \mathrm{O}$ neurons before the injection of the MOPR-selective agonist. After intrathecal injection of DAMGO $(5 \mu \mathrm{g})$, the DNICs triggered by noxious mechanical stimulation of the hindpaw were strongly reduced (Fig. $4 B$ ). Figure $4 D$ illustrates the results of the quantitative analysis. Ten to $20 \mathrm{~min}$ and 30-40 min after DAMGO injection, mechanically induced inhibition of C-fiber-evoked responses was $23 \pm 9 \%$ and $29 \pm 7 \%$, respectively. The DNICs were therefore reduced by $64 \pm 13 \%$ and $53 \pm 7 \%(p<0.0001, F=22.90$, one-way ANOVA for repeated measures followed by Bonferroni's multiple-comparison test). The specificity of the effects of intrathecally administered DAMGO upon the DNIC was tested by administering the opiate antagonist naloxone. For all the neurons tested, systemic administration of naloxone (intravenous injection, $0.4 \mathrm{mg} / \mathrm{kg}$ ) antagonized the reduction of the DNIC induced by DAMGO (Fig. $4 C, D)$.

In animals where Dlt II was tested $(n=9)$, application of a $300 \mathrm{~g}$ pressure to the hindpaw of the rats before the administration of the DOPR-selective agonist reduced by $57 \pm 7 \%$ the C-fiber-evoked action potentials of Sp5O WDR neurons. The 
intrathecal injection of Dlt II strongly reduced the inhibitory effects evoked by noxious mechanical stimulation of the hindpaw (Fig. 4F). Ten to 20 and 30-40 minutes after the administration of Dlt II, the inhibitions of C-fiber-evoked responses during the $300 \mathrm{~g}$ pressure application were $28 \pm 7 \%$ and $46 \pm 11 \%$, respectively (Fig. $4 H$ ). In brief, spinally administered Dlt II induced reductions of $51 \pm 14 \%$ and $25 \pm$ $13 \%$ of the DNICs. Indeed, the effect of Dlt II is only significant $10-20$ min after its administration $(p<0.0002, F=10.00$, one-way ANOVA for repeated measures followed by Bonferroni's multiple-comparison test). The selectivity of the effects of intrathecally administered Dlt II upon the heat-induced DNICs was tested by administering the DOPR-selective antagonist naltrindole. For all the tested neurons, systemic administration of naltrindole (intravenous injection $4 \mathrm{mg} / \mathrm{kg}$ ) antagonized the effect of Dlt II, indicating that it was DOPRmediated (Fig. 4G,H).

As for thermal stimulation, intrathecal DAMGO and Dlt II have comparable inhibitory effects on mechanically induced DNICs $(p=0.1654, F=2.13$, two-way ANOVA for repeated measures followed by Bonferroni's multiple-comparison test).

Interestingly, when the effects of intrathecal injection of DAMGO on the DNICs triggered by either noxious heat or mechanical stimulation were compared, no significant difference was found $(p=0.643$, $F=0.2244$, two-way ANOVA for repeated measures followed by Bonferroni's multiple-comparison test). Similarly, Dlt II was found to inhibit DNICs triggered by either noxious heat or mechanical stimulation with comparable potencies ( $p=$ 0.499, $F=0.48$, two-way ANOVA for repeated measures followed by Bonferroni's multiple-comparison test).

\section{The effects of intrathecal DAMGO and Dlt II injection on mechanically induced $\mathrm{NK}_{1}$ receptor internalization} As seen for noxious heat stimulation, application of a $300 \mathrm{~g}$ pressure induced a strong $\mathrm{NK}_{1}$ receptor internalization (Fig. 5B; $66 \pm$ $5 \%$ of ipsilateral lamina I neurons). Only discrete $\mathrm{NK}_{1}$ receptor internalization was observed in the contralateral side of the lumbar spinal cord (Fig. 5A). In animals pretreated with intrathecal DAMGO (Fig. $5 C$ ) or Dlt II (Fig. 5D), a significant decrease in the proportion of neurons showing $\mathrm{NK}_{1}$ receptor internalization was observed (Fig. $5 E ; 33 \pm 7 \%$ and $38 \pm 4 \%$, respectively, for DAMGO and Dlt II, of ipsilateral laminae I neurons have internalized $\mathrm{NK}_{1}$ receptors). This result corresponds to a reduction of
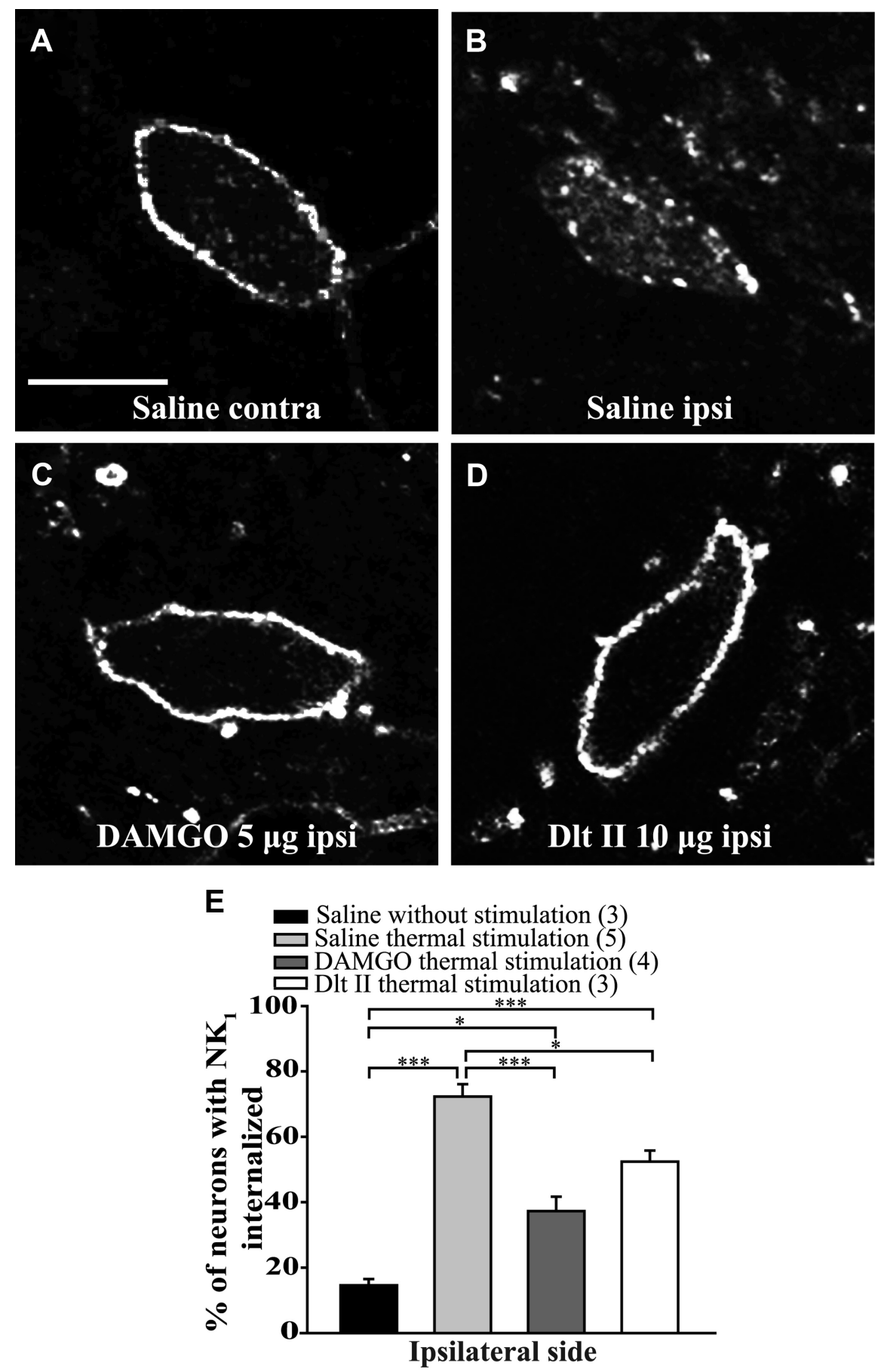

Figure 3. Intrathecal DAMGO and Dlt II reduce heat-induced $\mathrm{NK}_{1}$ receptor internalization. Internalization of $\mathrm{NK}_{1}$ receptors was induced by immersing the right hindpaw of male Sprague Dawley rats in a $49^{\circ} \mathrm{C}$ water bath for $38 \mathrm{~s}$, and lamina I NK$K_{1}$ receptorimmunoreactive neurons were observed by immunofluorescence. The noxious heat stimulation was applied $10 \mathrm{~min}$ after intrathecal injection of saline $(\boldsymbol{A}, \boldsymbol{B})$, DAMG0 $5 \mu \mathrm{g}(\boldsymbol{C})$, or Dlt II $10 \mu \mathrm{g}(\boldsymbol{D})$. Confocal images of neurons on the contralateral $(\boldsymbol{A})$ and ipsilateral $(\boldsymbol{B}-\boldsymbol{D})$ sides of the spinal cord are shown. On the contralateral side of the saline-injected animals, immunolabeling of NK receptors appeared to be at the cell surface $(\boldsymbol{A})$. However, on the ipsilateral side of the same animals, the noxious heat stimulation induced a significant increase in $\mathrm{NK}_{1}$ receptor internalization, as evidenced by the intensely labeled intracellular vesicle-like structures $(\boldsymbol{B})$. When DAMGO $(\boldsymbol{C})$ or Dlt II $(\boldsymbol{D})$ was injected, a significant reduction in $\mathrm{NK}_{1}$ receptor internalization was observed on the ipsilateral side compared with the same side in saline-injected rats. The animals that had received a saline injection but no noxious stimulation had low basal proportions of neurons with internalized $\mathrm{NK}_{1}$ receptors. This result is illustrated in the graphic representation showing the percentage of neurons with $\mathrm{NK}_{1}$ receptor internalization induced by heat stimulation for ipsilateral side of the lumbar spinal cord (E). ${ }^{*} p<0.05$ (one-way ANOVA with Bonferroni's post hoc test). ${ }^{* *} p<0.001$ (one-way ANOVA with Bonferroni's post hoc test). The numbers in parentheses represent the number of animals per group. Error bars indicate the SEM. Scale bar: $A, 30 \mu \mathrm{m}$. 

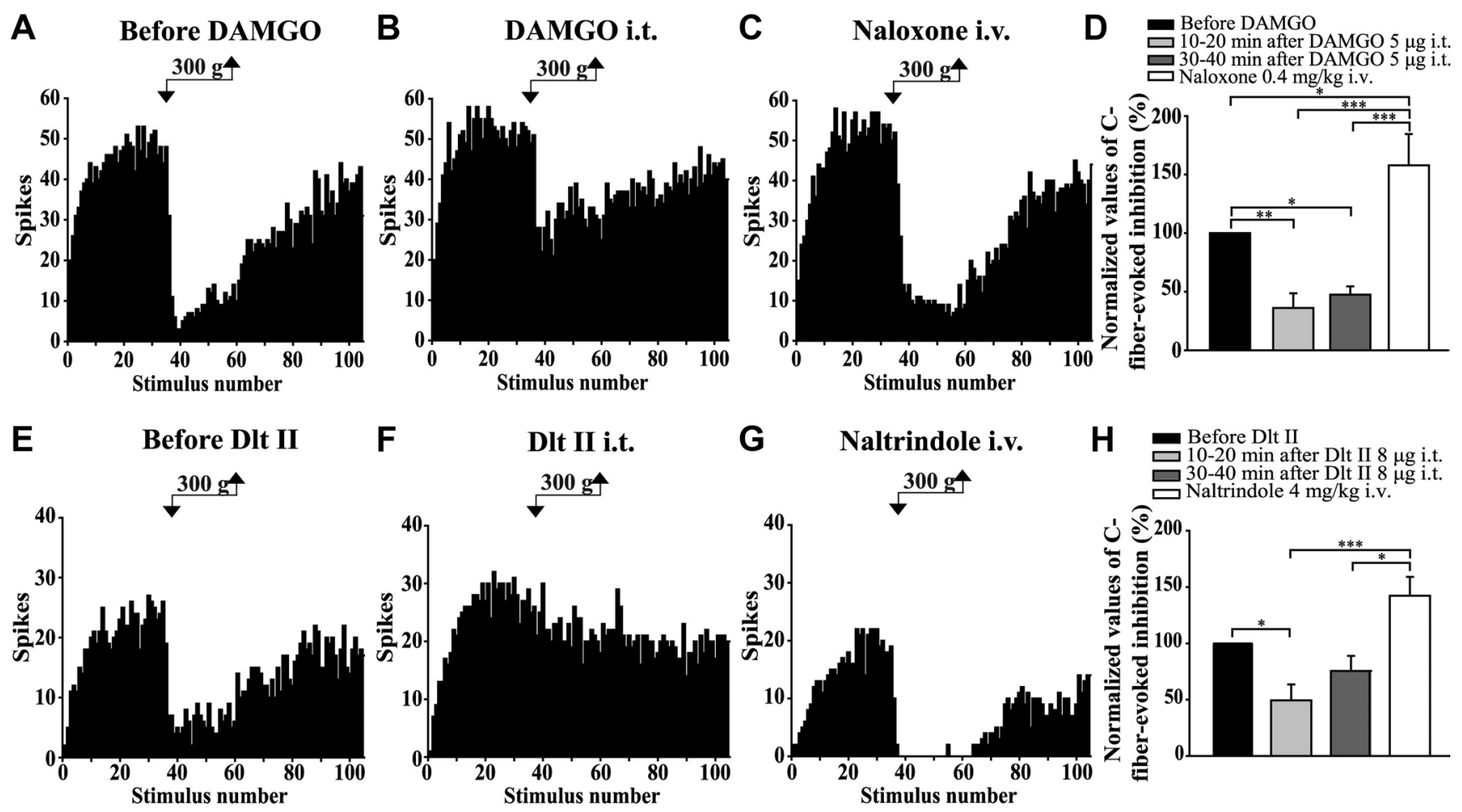

Figure 4. Intrathecal DAMGO and DIt II both inhibit the DNIC triggered by a noxious mechanical stimulus. $A-C, E-G$, Histograms showing representative $(-$ fiber-evoked responses of two trigeminal WDR neurons to 105 successive electrical stimulations recorded before $(\boldsymbol{A}, \boldsymbol{E})$ and $30 \mathrm{~min}$ after intrathecal (i.t.) administration of DAMG0 $5 \mu \mathrm{g}(\boldsymbol{B})$ or $10 \mathrm{~min}$ after Dlt II $8 \mu \mathrm{g}(\boldsymbol{F})$. Between the 36th and 60th stimulation, a $300 \mathrm{~g}$ mechanical pressure was applied on one hindpaw of the animal with calibrated forceps. The DNICs triggered by mechanical noxious stimulation of the hindpaw are reduced after both DAMGO $(\boldsymbol{B})$ and DIt II $(\boldsymbol{F})$ injection. The intravenous (i.v.) administration of naloxone $(\boldsymbol{C})$ and naltrindole $(\boldsymbol{G})$ reversed the effect of DAMGO and Dlt II, respectively. $\boldsymbol{D}, \boldsymbol{H}$, Graphic representation showing the mean $(n=8$ for $\boldsymbol{D}$, and $n=9$ for $\boldsymbol{H})$ percentage of inhibition of C-fiber-evoked action potentials before and $10-20$ min and $30-40$ min after the intrathecal injection of the opioids. The data are individually normalized to those before administration of the drugs. The selective-MOPR agonist significantly reduced the percentage of inhibition of C-fiber-evoked action potentials either $10-20$ or $30-40$ min after its administration. Naloxone significantly reversed those opioidergic-induced effects (D). The selective-DOPR agonist significantly reduced the percentage of inhibition of C-fiber-evoked action potentials only $10-20$ min after its administration and naltrindole significantly reversed this DOPR-mediated effect (D). ${ }^{*} p<0.05$ (one-way ANOVA for repeated measures with Bonferroni's post hoc test). ${ }^{* *} p<0.01$ (one-way ANOVA for repeated measures with Bonferroni's post hoc test). ${ }^{* *} p<0.001$ (one-way ANOVA for repeated measures with Bonferroni's post hoc test). Error bars indicate the SEM.

$\sim 50 \%$ and $42 \%$ of laminae I neurons with internalized $\mathrm{NK}_{1}$ receptors. In addition, there is no significant difference between the effects of DAMGO and Dlt II on inhibition of mechanically induced $\mathrm{NK}_{1}$ receptor internalization (Fig. $5 E ; p=0.0002, F=13.82$, one-way ANOVA followed by Bonferroni's multiple-comparison test).

Heat-induced and mechanically induced $\mathrm{NK}_{1}$ receptor internalization in mice

We then studied the effects of noxious heat and mechanical stimuli on the internalization of $\mathrm{NK}_{1}$ receptors in mice. We observed the localization of $\mathrm{NK}_{1}$ receptors after either immersion of the right hindpaw of mice in a $49^{\circ} \mathrm{C}$ waterbath or application of a $200 \mathrm{~g}$ pressure with calibrated forceps for $38 \mathrm{~s}$. As shown in Figure 6 , in control mice the $\mathrm{NK}_{1}$ receptor labeling was mostly found at the cell surface (Fig. $6 A, D ; 14 \pm 1 \%$ of lamina I neurons had internalized $\mathrm{NK}_{1}$ receptors). Immersion of the hindpaw in the $49^{\circ} \mathrm{C}$ waterbath induced a strong proportion of internalized $\mathrm{NK}_{1}$ receptors (Fig. $6 B, D ; 71 \pm 2 \%$ of neurons). Application of the mechanical pressure also induced a significant internalization of $\mathrm{NK}_{1}$ receptors (Fig. $6 C, D ; 53 \pm 4 \%$ of lamina I neurons have internalized $\mathrm{NK}_{1}$ receptors).

\section{Discussion}

In the present study, we investigated the role of spinal MOPRs and DOPRs in heat and mechanical pain regulation using electrophysiological and immunohistochemical approaches. By measuring the firing of WDR neurons of the spinal trigeminal subnucleus oralis ( $\mathrm{Sp} 5 \mathrm{O}$ ), we demonstrated that intrathecal administration of either DAMGO or Dlt II, respectively, MOPRand DOPR-selective agonists, was able to inhibit the activation of DNICs triggered by heat and mechanical noxious stimuli. We further observed that both spinal MOPR and DOPR activation blocks substance $\mathrm{P}$ release and inhibits $\mathrm{NK}_{1}$ receptor internalization induced by thermal and mechanical stimuli.

The existence of polymodal nociceptors implies that discrimination of pain modalities occurs at the higher spinal cord level and in the brain (Melzack and Wall, 1962; Perl, 2007). This dogma was, however, recently challenged. Indeed, using pharmacological ablation of mouse sensory neurons expressing the sodium channel $\mathrm{Na}_{\mathrm{v}} 1.8$ or genetic ablation of Mrgprd-expressing sensory neurons, others revealed that specific pain modalities are encoded by distinct subpopulations of nociceptors (Abrahamsen et al., 2008; Cavanaugh et al., 2009). These findings were further supported by the fact that, in mice, nonpeptidergic IB4-positive DRG neurons were found to specifically mediate the responses to mechanical pain, whereas a subpopulation of IB4-negative neurons mediates thermal pain (Scherrer et al., 2009).

In primary afferents, MOPR are mainly expressed by small IB4-negative peptidergic neurons (Ji et al., 1995; Minami et al., 1995; Zhang et al., 1998b; Wang and Wessendorf, 2001; Rau et al., 2005), whereas DOPR was found to be expressed in large- and small-diameter neurons (Mansour et al., 1994; Wang and Wessendorf, 2001). Although the presence of DOPR in substance 
P- and calcitonin gene-related peptidecontaining neurons has been shown (Ji et al., 1995; Zhang et al., 1998a; Riedl et al., 2009; Wang et al., 2010), enhanced green fluorescent protein-tagged DOPR is confined to nonpeptidergic fibers in knockin mice (Scherrer et al., 2009). In agreement with the hypothesis that specific pain modalities are encoded by distinct subpopulations of nociceptors, it was observed that spinal DAMGO specifically inhibited heatinduced pain whereas activation of spinal DOPR specifically attenuated mechanical stimuli-induced behaviors (Scherrer et al., 2009).

In the current study, we measured the effects of heat and mechanical noxious stimuli applied to the hindpaws of rats on the firing of trigeminal WDR neurons and confirmed previous studies showing the existence of DNIC acting on these trigeminal neurons (Le Bars, 2002; Lapirot et al., 2011). As opposed to stimulus-induced reflex or withdrawal responses studied in most behavioral tests, DNICs can only be triggered by noxious stimuli (Le Bars et al., 1979) and therefore represent an efficient and unbiased strategy to evaluate the analgesic properties of drugs applied intrathecally. Here, we demonstrated that activation of both MOPR and DOPR at the spinal level resulted in a profound decrease in the effects of the DNIC on the firing of WDR neurons. Indeed, intrathecal DAMGO and Dlt II were able to similarly reduce the effects of the DNIC induced by heat or mechanical noxious stimulation of the hindpaw. The fact that intrathecal administration of DAMGO or Dlt II alone had no effect on C-fiberevoked responses of trigeminal WDR neurons in the absence of heterotopic conditioning stimuli suggests that the reduction of DNIC-induced analgesia does not result from direct action of MOPR or DOPR agonists in the trigeminal nucleus.

The efficacy of MOPR agonists to inhibit mechanical pain in rodents has also been shown by others (Nakazawa et al., 1985; Chaki et al., 1988; Nichols et al., 1995; Kondo et al., 2005; Back et al., 2006; Iwai et al., 2012; Lee et al., 2012). Similarly, a number of studies demonstrated that intrathecal DOPR agonists efficiently alleviate noxious heat-induced behaviors in rats and in mice (Stewart and Hammond, 1994; Tseng et al., 1997; Qiu et al., 2000; Cahill et al., 2001, 2003; Morinville et al., 2003; Gendron et al., 2007a, b; Beaudry et al., 2009, 2011; Overland et al., 2009; Dubois and Gendron, 2010). Lessons from knock-out mice also provided evidence supporting a role for MOPR and DOPR in the modulation of diverse pain modalities. Indeed, both $M O P R$ and
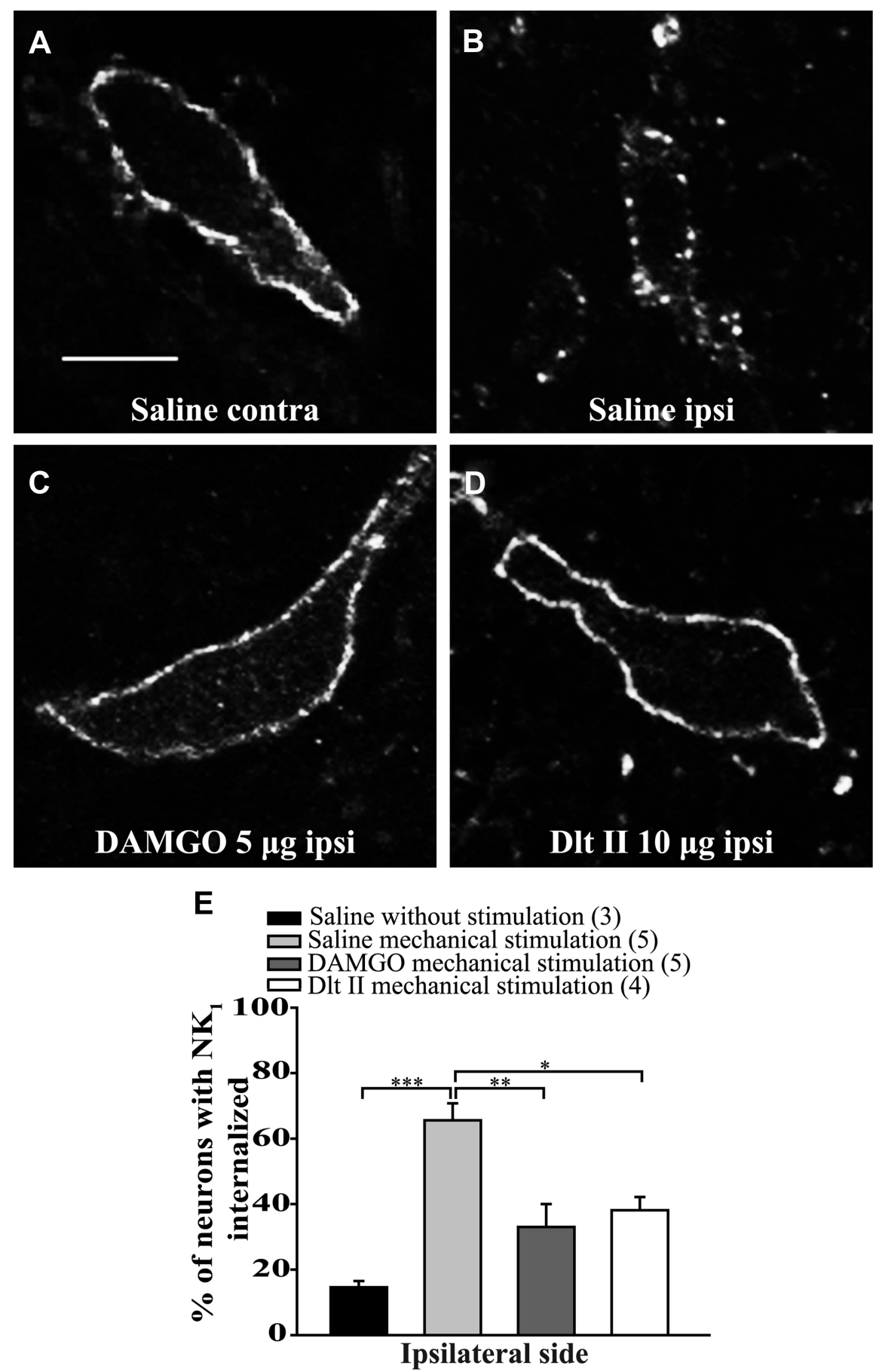

Figure 5. Intrathecal DAMGO and DIt II reduce mechanical stimulus-induced $N K_{1}$ receptor internalization. Internalization of $N K_{1}$ receptors was induced by applying a $300 \mathrm{~g}$ mechanical pressure on the right hindpaw with calibrated forceps for $38 \mathrm{~s}$. Lamina I NK 1 receptorimmunoreactive neurons were observed by immunofluorescence. The noxious mechanical stimulation was applied 10 min after intrathecal injection of saline $(\boldsymbol{A}, \boldsymbol{B}), \mathrm{DAMGO} 5 \mu \mathrm{g}(\boldsymbol{C})$, or Dlt II $10 \mu \mathrm{g}$ (D). Confocal images showed that application of the mechanical pressure did not affect the cell-surface localization of $\mathrm{NK}_{1}$ receptors in the contralateral side of the lumbar spinal cord of saline-injected rats $(A)$. In contrast, application of the same stimulus induced a strong internalization of $\mathrm{NK}_{1}$ receptors in the ipsilateral side for the same animal, as shown by the intracellular localization of the immunolabeling $(\boldsymbol{B})$. The injection of DAMGO or Dlt Il both significantly inhibited mechanically induced NK receptor internalization $(\boldsymbol{E})$. For comparison purposes, data from the saline-injected group without noxious stimulation presented in Fig. $3 E$ are reported in panel $E$. ${ }^{*} p<0.05$ (one-way ANOVA with Bonferroni's post hoc test). ${ }^{* *} p<0.01$ (one-way ANOVA with Bonferroni's post hoc test). ${ }^{* *} p<0.001$ (one-way ANOVA with Bonferroni's post hoc test). Values in parentheses represent the number of animals per group. Error bars indicate the SEM. Scale bar: $A, 30 \mu \mathrm{m}$.

DOPR knock-out mice were found to have increased sensitivity to thermal (Sora et al., 1997; Matthes et al., 1998; Qiu et al., 2000; Martin et al., 2003) and mechanical pain (Martin et al., 2003). 

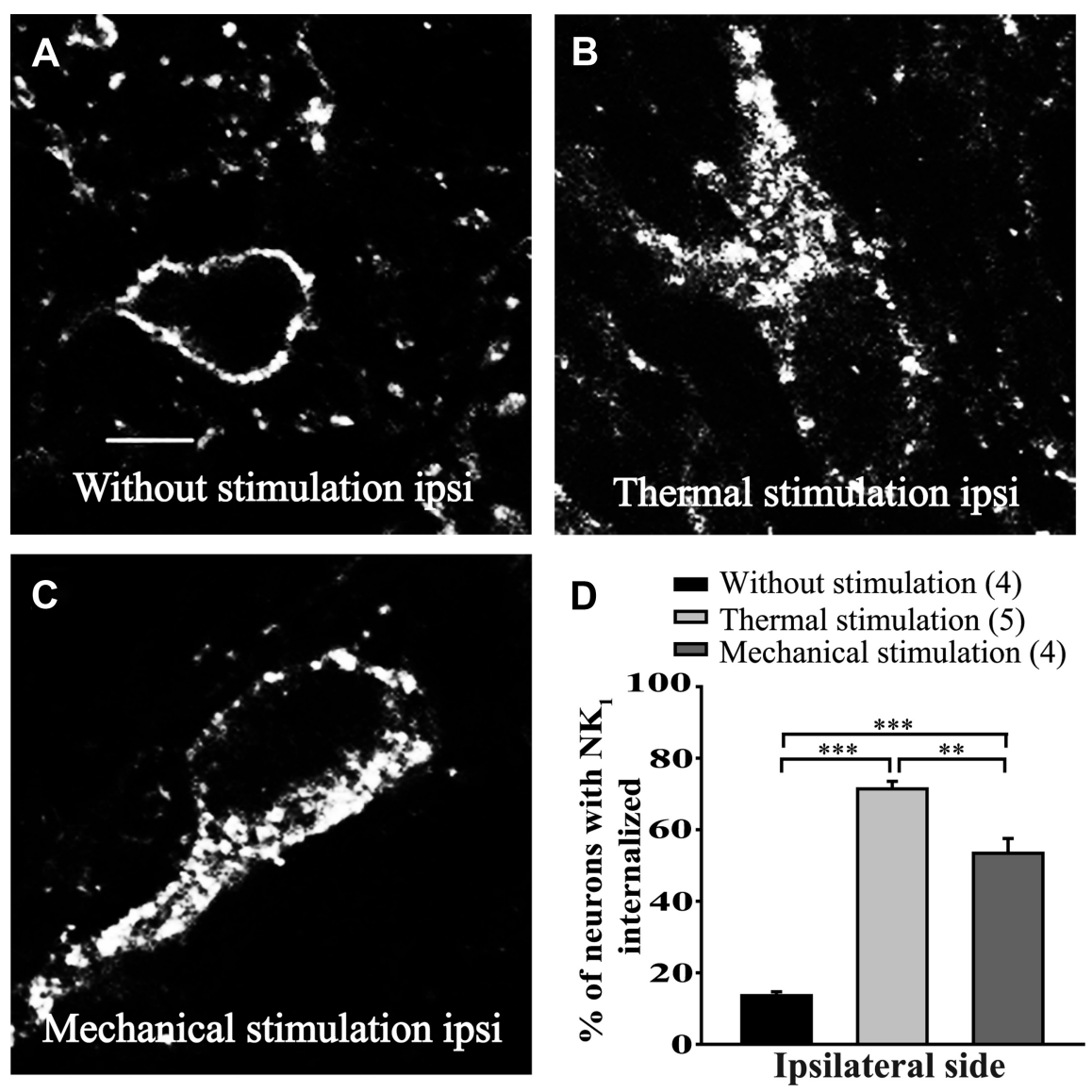

Figure 6. Heat-induced and mechanically induced $\mathrm{NK}_{1}$ receptor internalization in mice. In mice, internalization of NK ${ }_{1}$ receptors was induced by immersion of the right hindpaw for $38 \mathrm{~s}$ in a $49^{\circ} \mathrm{C}$ water bath or by applying (with calibrated forceps) a $200 \mathrm{~g}$ mechanical pressure on the right hindpaw, also for $38 \mathrm{~s}$. Animals were perfused without receiving any noxious stimulation $(\boldsymbol{A}), 10$

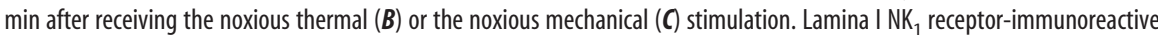
neurons were observed by immunofluorescence. Confocal images showed that nonstimulated animals present a cell-surface localization of $\mathrm{NK}_{1}$ receptor labeling $(\boldsymbol{A})$. Application of the thermal stimulus $(\boldsymbol{B})$ or the mechanical pressure $(\boldsymbol{C})$ both induces strong internalization of $\mathrm{NK}_{1}$ receptors in the ipsilateral side of the lumbar segment of the spinal cord $(\boldsymbol{D}) .{ }^{* *} p<0.01$ (one-way ANOVA with Bonferroni's post hoc test). ${ }^{* * *} p<0.001$ (one-way ANOVA with Bonferroni's post hoc test). Values in parentheses represent the number of animals per group. Error bars indicate the SEM. Scale bar: $\boldsymbol{A}, 30 \mu \mathrm{m}$.

In accordance with the polymodal nature of nociceptors, peripheral thermal (Zachariou and Goldstein, 1996; Abbadie et al., 1997; Allen et al., 1997; King et al., 2005), mechanical (McCarson and Goldstein, 1991; Zachariou and Goldstein, 1996; Abbadie et al., 1997; King et al., 2005; Kondo et al., 2005), and chemical (Marvizon et al., 2003; Nazarian et al., 2008; Beaudry et al., 2011) noxious stimulations were shown to evoke the release of substance $\mathrm{P}$ in the superficial layers of the rat spinal cord. Interestingly, the blockade of $\mathrm{NK}_{1}$ receptors expressed by spinoparabrachial neurons was previously shown to inhibit DNICs triggered by intraplantar formalin (Lapirot et al., 2009). To determine whether DAMGO and Dlt II can inhibit the release of substance $\mathrm{P}$ induced by heat and mechanical noxious stimulation of the hindpaw in rats, we measured $\mathrm{NK}_{1}$ receptor internalization in the superficial laminae of the lumbar spinal cord. As shown previously (Kondo et al., 2005; Zhang et al., 2010), we observed that DAMGO blocked the $\mathrm{NK}_{1}$ receptor internalization induced by noxious mechanical stimulation. We also showed, for the first time, that intrathecal DAMGO decreased the $\mathrm{NK}_{1}$ receptor internalization evoked by noxious heat stimulation of the paw. Similarly, intrathecal Dlt II blocked $\mathrm{NK}_{1}$ receptor internalization induced by heat and me- chanical noxious stimuli. The fact that intrathecally injected Dlt II has an effect on $\mathrm{NK}_{1}$ receptor internalization confirms previous reports showing that a subpopulation of substance P-containing nociceptors expresses DOPRs (Ji et al., 1995; Zhang et al., 1998a; Riedl et al., 2009; Wang et al., 2010; Beaudry et al., 2011). Our results also reveal that peptidergic primary afferents are involved in DNICs triggered by noxious heat and mechanical stimulations and that these fibers are regulated by both MOPRs and DOPRs.

One may argue that the apparent discrepancies between our observations and those made by others could be explained by interspecies differences. Indeed, as previously mentioned, a dichotomy between C-fiber subpopulations and pain modalities was observed in mice (Abrahamsen et al., 2008; Cavanaugh et al., 2009; Scherrer et al., 2009). Thus, transient receptor potential vanilloid 1 , an important but not unique transducer of thermal nociception (Caterina et al., 2000; Davis et al., 2000; Woodbury et al., 2004), is almost exclusively found in heat-specific peptidergic sensory neurons in mice (Zwick et al., 2002; Woodbury et al., 2004; Lawson et al., 2008; Cavanaugh et al., 2011) while it is found in both peptidergic and nonpeptidergic C-fibers in rats (Gold et al., 1996; Tominaga et al., 1998; Guo et al., 1999; Michael and Priestley, 1999; Woodbury et al., 2004; Yu et al., 2008). Others hypothesized that the observed dichotomy between $\mathrm{C}$-fiber populations and nociceptive modalities; thus, the effects of intrathecal MOPR and DOPR agonists may not apply to rats or higher-order primates (Saeed and Ribeiro-da-Silva, 2012; Taylor et al., 2012). For instance, we observed here that both noxious thermal and mechanical stimuli can induce $\mathrm{NK}_{1}$ receptor internalization in both rats and mice, confirming that peptidergic primary afferents participate in thermal and mechanical nociception in both species.

Alternatively, it is possible that the mechanical stimuli used by Scherrer et al. (2009), namely, von Frey filaments, were not noxious and therefore that paw withdrawals were the consequence of stimulation of non-nociceptive $\mathrm{A} \delta$ and/or $\mathrm{A} \beta$-fibers shown to express DOPR. von Frey filaments are indeed commonly used to measure allodynia, that is, pain induced by a non-noxious stimulus (e.g., light touch), in injured or sensitized subjects. As a noxious mechanical stimulus, we rather used a $200 \mathrm{~g}$ (mice) or $300 \mathrm{~g}$ (rats) pressure applied for $38 \mathrm{~s}$ to the hindpaw with calibrated forceps and show that it efficiently recruits mechanical nociceptors, induces the release of substance $\mathrm{P}$ by primary afferents and, most importantly, activates DNICs, which are only triggered by noxious stimuli.

In conclusion, our results reveal that the activation of either MOPR or DOPR can equally relieve both pain modalities (i.e., thermal and mechanical), possibly via direct action on peptidergic C-fibers. Admittedly, although we found that spi- 
nal DAMGO and Dlt II similarly inhibited the DNIC triggered by heat and mechanical noxious stimuli applied to the hindpaws, other MOPR and DOPR agonists may not be equally potent at inhibiting all pain modalities. As an example, neuropathic pain is often found to be less sensitive than inflammatory pain to MOPR agonists (Arner and Meyerson, 1988; Obara et al., 2009). Despite the fact that we cannot exclude that spinal DAMGO and Dlt II could inhibit multiple subpopulations of selective heat-sensitive and mechanosensitive nociceptors, the current study revealed that peptidergic $\mathrm{C}$-fibers are involved in heat and mechanical pain processing in rodents, a hypothesis recently challenged by others (Cavanaugh et al., 2009; Scherrer et al., 2009).

\section{References}

Abbadie C, Trafton J, Liu H, Mantyh PW, Basbaum AI (1997) Inflammation increases the distribution of dorsal horn neurons that internalize the neurokinin-1 receptor in response to noxious and non-noxious stimulation. J Neurosci 17:8049-8060. Medline

Abrahamsen B, Zhao J, Asante CO, Cendan CM, Marsh S, MartinezBarbera JP, Nassar MA, Dickenson AH, Wood JN (2008) The cell and molecular basis of mechanical, cold, and inflammatory pain. Science 321:702-705. CrossRef Medline

Allen BJ, Rogers SD, Ghilardi JR, Menning PM, Kuskowski MA, Basbaum AI, Simone DA, Mantyh PW (1997) Noxious cutaneous thermal stimuli induce a graded release of endogenous substance $\mathrm{P}$ in the spinal cord: imaging peptide action in vivo. J Neurosci 17:5921-5927. Medline

Arnér S, Meyerson BA (1988) Lack of analgesic effect of opioids on neuropathic and idiopathic forms of pain. Pain 33:11-23. CrossRef Medline

Back SK, Lee J, Hong SK, Na HS (2006) Loss of spinal $\mu$-opioid receptor is associated with mechanical allodynia in a rat model of peripheral neuropathy. Pain 123:117-126. CrossRef Medline

Beaudry H, Proteau-Gagné A, Li S, Dory Y, Chavkin C, Gendron L (2009) Differential noxious and motor tolerance of chronic $\delta$ opioid receptor agonists in rodents. Neuroscience 161:381-391. CrossRef Medline

Beaudry H, Dubois D, Gendron L (2011) Activation of spinal $\mu$ - and $\delta$-opioid receptors potently inhibits substance $\mathrm{P}$ release induced by peripheral noxious stimuli. J Neurosci 31:13068-13077. CrossRef Medline

Cahill CM, Morinville A, Lee MC, Vincent JP, Collier B, Beaudet A (2001) Prolonged morphine treatment targets $\delta$ opioid receptors to neuronal plasma membranes and enhances $\delta$-mediated antinociception. J Neurosci 21:7598-7607. Medline

Cahill CM, Morinville A, Hoffert C, O’Donnell D, Beaudet A (2003) Upregulation and trafficking of $\delta$ opioid receptor in a model of chronic inflammation: implications for pain control. Pain 101:199-208. CrossRef Medline

Cain DM, Khasabov SG, Simone DA (2001) Response properties of mechanoreceptors and nociceptors in mouse glabrous skin: an in vivo study. J Neurophysiol 85:1561-1574. Medline

Caterina MJ, Leffler A, Malmberg AB, Martin WJ, Trafton J, Petersen-Zeitz KR, Koltzenburg M, Basbaum AI, Julius D (2000) Impaired nociception and pain sensation in mice lacking the capsaicin receptor. Science 288: 306-313. CrossRef Medline

Cavanaugh DJ, Lee H, Lo L, Shields SD, Zylka MJ, Basbaum AI, Anderson DJ (2009) Distinct subsets of unmyelinated primary sensory fibers mediate behavioral responses to noxious thermal and mechanical stimuli. Proc Natl Acad Sci U S A 106:9075-9080. CrossRef Medline

Cavanaugh DJ, Chesler AT, Bráz JM, Shah NM, Julius D, Basbaum AI (2011) Restriction of transient receptor potential vanilloid-1 to the peptidergic subset of primary afferent neurons follows its developmental downregulation in nonpeptidergic neurons. J Neurosci 31: 10119-10127. CrossRef Medline

Chaki K, Sakurada S, Sakurada T, Sato T, Kawamura S, Kisara K, Watanabe H, Suzuki K (1988) Comparison of the antinociceptive effects of new [DArg2]-dermorphin tetrapeptide analogs and morphine in mice. Pharmacol Biochem Behav 31:439-444. CrossRef Medline

Chen SR, Pan HL (2006) Loss of TRPV1-expressing sensory neurons reduces spinal $\mu$ opioid receptors but paradoxically potentiates opioid analgesia. J Neurophysiol 95:3086-3096. CrossRef Medline

Coste J, Voisin DL, Luccarini P, Dallel R (2008a) A role for wind-up in trigeminal sensory processing: intensity coding of nociceptive stimuli in the rat. Cephalalgia 28:631-639. CrossRef Medline

Coste J, Voisin DL, Miraucourt LS, Dallel R, Luccarini P (2008b) Dorsal horn NK1-expressing neurons control windup of downstream trigeminal nociceptive neurons. Pain 137:340-351. CrossRef Medline

Dallel R, Duale C, Luccarini P, Molat JL (1999) Stimulus-function, wind-up and modulation by diffuse noxious inhibitory controls of responses of convergent neurons of the spinal trigeminal nucleus oralis. Eur J Neurosci 11:31-40. CrossRef Medline

Davis JB, Gray J, Gunthorpe MJ, Hatcher JP, Davey PT, Overend P, Harries MH, Latcham J, Clapham C, Atkinson K, Hughes SA, Rance K, Grau E, Harper AJ, Pugh PL, Rogers DC, Bingham S, Randall A, Sheardown SA (2000) Vanilloid receptor-1 is essential for inflammatory thermal hyperalgesia. Nature 405:183-187. CrossRef Medline

Dubois D, Gendron L (2010) $\delta$ opioid receptor-mediated analgesia is not altered in preprotachykinin A knockout mice. Eur J Neurosci 32:19211929. CrossRef Medline

Fairbanks CA (2003) Spinal delivery of analgesics in experimental models of pain and analgesia. Adv Drug Deliv Rev 55:1007-1041. CrossRef Medline

Gendron L, Pintar JE, Chavkin C (2007a) Essential role of $\mu$ opioid receptor in the regulation of $\delta$ opioid receptor-mediated antihyperalgesia. Neuroscience 150:807-817. CrossRef Medline

Gendron L, Esdaile MJ, Mennicken F, Pan H, O'Donnell D, Vincent JP, Devi LA, Cahill CM, Stroh T, Beaudet A (2007b) Morphine priming in rats with chronic inflammation reveals a dichotomy between antihyperalgesic and antinociceptive properties of deltorphin. Neuroscience 144:263-274. CrossRef Medline

Gold MS, Dastmalchi S, Levine JD (1996) Co-expression of nociceptor properties in dorsal root ganglion neurons from the adult rat in vitro. Neuroscience 71:265-275. CrossRef Medline

Guo A, Vulchanova L, Wang J, Li X, Elde R (1999) Immunocytochemical localization of the vanilloid receptor 1 (VR1): relationship to neuropeptides, the P2X3 purinoceptor and IB4 binding sites. Eur J Neurosci 11: 946-958. CrossRef Medline

Holdridge SV, Cahill CM (2007) Spinal administration of a $\delta$ opioid receptor agonist attenuates hyperalgesia and allodynia in a rat model of neuropathic pain. Eur J Pain 11:685-693. CrossRef Medline

Hu JW (1990) Response properties of nociceptive and non-nociceptive neurons in the rat's trigeminal subnucleus caudalis (medullary dorsal horn) related to cutaneous and deep craniofacial afferent stimulation and modulation by diffuse noxious inhibitory controls. Pain 41:331345. CrossRef Medline

Iwai S, Kiguchi N, Kobayashi Y, Fukazawa Y, Saika F, Ueno K, Yamamoto C, Kishioka S (2012) Inhibition of morphine tolerance is mediated by painful stimuli via central mechanisms. Drug Discov Ther 6:31-37. CrossRef Medline

Ji RR, Zhang Q, Law PY, Low HH, Elde R, Hökfelt T (1995) Expression of $\mu$-, $\delta$-, and $\kappa$-opioid receptor-like immunoreactivities in rat dorsal root ganglia after carrageenan-induced inflammation. J Neurosci 15:81568166. Medline

Julius D, Basbaum AI (2001) Molecular mechanisms of nociception. Nature 413:203-210. CrossRef Medline

King T, Gardell LR, Wang R, Vardanyan A, Ossipov MH, Malan TP Jr, Vanderah TW, Hunt SP, Hruby VJ, Lai J, Porreca F (2005) Role of NK-1 neurotransmission in opioid-induced hyperalgesia. Pain 116: 276-288. CrossRef Medline

Koltzenburg M, Stucky CL, Lewin GR (1997) Receptive properties of mouse sensory neurons innervating hairy skin. J Neurophysiol 78:1841-1850. Medline

Kondo I, Marvizon JC, Song B, Salgado F, Codeluppi S, Hua XY, Yaksh TL (2005) Inhibition by spinal $\mu$ - and $\delta$-opioid agonists of afferent-evoked substance P release. J Neurosci 25:3651-3660. CrossRef Medline

Lapirot O, Chebbi R, Monconduit L, Artola A, Dallel R, Luccarini P (2009) NK1 receptor-expressing spinoparabrachial neurons trigger diffuse noxious inhibitory controls through lateral parabrachial activation in the male rat. Pain 142:245-254. CrossRef Medline

Lapirot O, Melin C, Modolo A, Nicolas C, Messaoudi Y, Monconduit L, Artola A, Luccarini P, Dallel R (2011) Tonic and phasic descending dopaminergic controls of nociceptive transmission in the medullary dorsal horn. Pain 152:1821-1831. CrossRef Medline

Lawson JJ, Mcllwrath SL, Woodbury CJ, Davis BM, Koerber HR (2008) TRPV1 unlike TRPV2 is restricted to a subset of mechanically insensitive 
cutaneous nociceptors responding to heat. J Pain 9:298-308. CrossRef Medline

Le Bars D (2002) The whole body receptive field of dorsal horn multireceptive neurones. Brain Res Brain Res Rev 40:29-44. CrossRef Medline

Le Bars D, Dickenson AH, Besson JM (1979) Diffuse noxious inhibitory controls (DNIC): I. Effects on dorsal horn convergent neurones in the rat. Pain 6:283-304. CrossRef Medline

Lee BS, Jun IG, Kim SH, Park JY (2012) Interaction of morphine and selective serotonin receptor inhibitors in rats experiencing inflammatory pain. J Korean Med Sci 27:430-436. CrossRef Medline

Malmberg AB, Yaksh TL (1992) Isobolographic and dose-response analyses of the interaction between intrathecal $\mu$ and $\delta$ agonists: effects of naltrindole and its benzofuran analog (NTB). J Pharmacol Exp Ther 263:264-275. Medline

Mansour A, Fox CA, Burke S, Meng F, Thompson RC, Akil H, Watson SJ (1994) $\mu, \delta$, and $\kappa$ opioid receptor mRNA expression in the rat CNS: an in situ hybridization study. J Comp Neurol 350:412-438. CrossRef Medline

Mantyh PW, DeMaster E, Malhotra A, Ghilardi JR, Rogers SD, Mantyh CR, Liu H, Basbaum AI, Vigna SR, Maggio JE, et al. (1995) Receptor endocytosis and dendrite reshaping in spinal neurons after somatosensory stimulation. Science 268:1629-1632. CrossRef Medline

Martin M, Matifas A, Maldonado R, Kieffer BL (2003) Acute antinociceptive responses in single and combinatorial opioid receptor knockout mice: distinct $\mu, \delta$ and $\kappa$ tones. Eur J Neurosci 17:701-708. CrossRef Medline

Marvizón JC, Wang X, Matsuka Y, Neubert JK, Spigelman I (2003) Relationship between capsaicin-evoked substance $\mathrm{P}$ release and neurokinin 1 receptor internalization in the rat spinal cord. Neuroscience 118:535-545. CrossRef Medline

Matthes HW, Smadja C, Valverde O, Vonesch JL, Foutz AS, Boudinot E, Denavit-Saubié M, Severini C, Negri L, Roques BP, Maldonado R, Kieffer BL (1998) Activity of the $\delta$-opioid receptor is partially reduced, whereas activity of the $\kappa$-receptor is maintained in mice lacking the $\mu$-receptor. J Neurosci 18:7285-7295. Medline

McCarson KE, Goldstein BD (1991) Release of substance P into the superficial dorsal horn following nociceptive activation of the hindpaw of the rat. Brain Res 568:109-115. CrossRef Medline

Melzack R, Wall PD (1962) On the nature of cutaneous sensory mechanisms. Brain 85:331-356. CrossRef Medline

Miaskowski C, Taiwo YO, Levine JD (1990) $\kappa$ - and $\delta$-opioid agonists synergize to produce potent analgesia. Brain Res 509:165-168. CrossRef Medline

Miaskowski C, Sutters KA, Taiwo YO, Levine JD (1991) Comparison of the antinociceptive and motor effects of intrathecal opioid agonists in the rat. Brain Res 553:105-109. CrossRef Medline

Michael GJ, Priestley JV (1999) Differential expression of the mRNA for the vanilloid receptor subtype 1 in cells of the adult rat dorsal root and nodose ganglia and its downregulation by axotomy. J Neurosci 19: 1844-1854. Medline

Minami M, Maekawa K, Yabuuchi K, Satoh M (1995) Double in situ hybridization study on coexistence of $\mu$-, $\delta$ - and $\kappa$-opioid receptor mRNAs with preprotachykinin A mRNA in the rat dorsal root ganglia. Brain Res Mol Brain Res 30:203-210. CrossRef Medline

Morinville A, Cahill CM, Esdaile MJ, Aibak H, Collier B, Kieffer BL, Beaudet A (2003) Regulation of $\delta$-opioid receptor trafficking via $\mu$-opioid receptor stimulation: evidence from $\mu$-opioid receptor knock-out mice. J Neurosci 23:4888-4898. Medline

Muthuraman A, Singh N (2011) Attenuating effect of Acorus calamus extract in chronic constriction injury induced neuropathic pain in rats: an evidence of anti-oxidative, anti-inflammatory, neuroprotective and calcium inhibitory effects. BMC Complement Altern Med 11:24. CrossRef Medline

Nagasaka H, Yaksh TL (1995) Effects of intrathecal $\mu, \delta$, and $\kappa$ agonists on thermally evoked cardiovascular and nociceptive reflexes in halothaneanesthetized rats. Anesth Analg 80:437-443. CrossRef Medline

Nakazawa T, Ikeda M, Kaneko T, Yamatsu K (1985) Analgesic effects of dynorphin-A and morphine in mice. Peptides 6:75-78. CrossRef Medline

Nazarian A, Gu G, Gracias NG, Wilkinson K, Hua XY, Vasko MR, Yaksh TL (2008) Spinal $N$-methyl-D-aspartate receptors and nociception-evoked release of primary afferent substance P. Neuroscience 152:119-127. CrossRef Medline
Nichols ML, Bian D, Ossipov MH, Lai J, Porreca F (1995) Regulation of morphine antiallodynic efficacy by cholecystokinin in a model of neuropathic pain in rats. J Pharmacol Exp Ther 275:1339-1345. Medline

Obara I, Parkitna JR, Korostynski M, Makuch W, Kaminska D, Przewlocka B, Przewlocki R (2009) Local peripheral opioid effects and expression of opioid genes in the spinal cord and dorsal root ganglia in neuropathic and inflammatory pain. Pain 141:283-291. CrossRef Medline

Otis V, Sarret P, Gendron L (2011) Spinal activation of $\delta$ opioid receptors alleviates cancer-related bone pain. Neuroscience 183:221-229. CrossRef Medline

Overland AC, Kitto KF, Chabot-Doré AJ, Rothwell PE, Fairbanks CA, Stone LS, Wilcox GL (2009) Protein kinase C mediates the synergistic interaction between agonists acting at $\alpha 2$-adrenergic and $\delta$-opioid receptors in spinal cord. J Neurosci 29:13264-13273. CrossRef Medline

Paxinos G, Watson C, eds (1997) The rat brain in stereotaxic coordinates, Ed 3. San Diego: Academic.

Perl ER (1996) Cutaneous polymodal receptors: characteristics and plasticity. Prog Brain Res 113:21-37. CrossRef Medline

Perl ER (2007) Ideas about pain, a historical view. Nat Rev Neurosci 8:7180. CrossRef Medline

Porreca F, Mosberg HI, Hurst R, Hruby VJ, Burks TF (1984) Roles of $\mu, \delta$ and $\kappa$ opioid receptors in spinal and supraspinal mediation of gastrointestinal transit effects and hot-plate analgesia in the mouse. J Pharmacol Exp Ther 230:341-348. Medline

Qiu C, Sora I, Ren K, Uhl G, Dubner R (2000) Enhanced $\delta$-opioid receptormediated antinociception in $\mu$-opioid receptor-deficient mice. Eur J Pharmacol 387:163-169. CrossRef Medline

Rau KK, Caudle RM, Cooper BY, Johnson RD (2005) Diverse immunocytochemical expression of opioid receptors in electrophysiologically defined cells of rat dorsal root ganglia. J Chem Neuroanat 29:255-264. CrossRef Medline

Riedl MS, Schnell SA, Overland AC, Chabot-Doré AJ, Taylor AM, Ribeiroda-Silva A, Elde RP, Wilcox GL, Stone LS (2009) Coexpression of $\alpha$ $2 \mathrm{~A}$-adrenergic and $\delta$-opioid receptors in substance P-containing terminals in rat dorsal horn. J Comp Neurol 513:385-398. CrossRef Medline

Saeed AW, Ribeiro-da-Silva A (2012) Non-peptidergic primary afferents are presynaptic to neurokinin-1 receptor immunoreactive lamina I projection neurons in rat spinal cord. Mol Pain 8:64. CrossRef Medline

Scherrer G, Imamachi N, Cao YQ, Contet C, Mennicken F, O’Donnell D, Kieffer BL, Basbaum AI (2009) Dissociation of the opioid receptor mechanisms that control mechanical and heat pain. Cell 137:11481159. CrossRef Medline

Sibilia V, Pagani F, Mrak E, Dieci E, Tulipano G, Ferrucci F (2012) Pharmacological characterization of the ghrelin receptor mediating its inhibitory action on inflammatory pain in rats. Amino Acids 43:1751-1759. CrossRef Medline

Sluka KA, Rohlwing JJ, Bussey RA, Eikenberry SA, Wilken JM (2002) Chronic muscle pain induced by repeated acid injection is reversed by spinally administered $\mu$ - and $\delta$-, but not $\kappa$-, opioid receptor agonists. J Pharmacol Exp Ther 302:1146-1150. CrossRef Medline

Sora I, Takahashi N, Funada M, Ujike H, Revay RS, Donovan DM, Miner LL, Uhl GR (1997) Opiate receptor knockout mice define $\mu$ receptor roles in endogenous nociceptive responses and morphine-induced analgesia. Proc Natl Acad Sci U S A 94:1544-1549. CrossRef Medline

Stein C, Lang LJ (2009) Peripheral mechanisms of opioid analgesia. Curr Opin Pharmacol 9:3-8. CrossRef Medline

Stewart PE, Hammond DL (1994) Activation of spinal $\delta$-1 or $\delta$-2 opioid receptors reduces carrageenan-induced hyperalgesia in the rat. J Pharmacol Exp Ther 268:701-708. Medline

Sutters KA, Miaskowski C, Taiwo YO, Levine JD (1990) Analgesic synergy and improved motor function produced by combinations of $\mu-\delta$ - and $\mu$ - $\kappa$-opioids. Brain Res 530:290-294. CrossRef Medline

Taylor AM, Osikowicz M, Ribeiro-da-Silva A (2012) Consequences of the ablation of nonpeptidergic afferents in an animal model of trigeminal neuropathic pain. Pain 153:1311-1319. CrossRef Medline

Tominaga M, Caterina MJ, Malmberg AB, Rosen TA, Gilbert H, Skinner K, Raumann BE, Basbaum AI, Julius D (1998) The cloned capsaicin receptor integrates multiple pain-producing stimuli. Neuron 21:531543. CrossRef Medline

Tseng LF, Narita M, Mizoguchi H, Kawai K, Mizusuna A, Kamei J, Suzuki T, Nagase H (1997) $\delta$-1 opioid receptor-mediated antinociceptive proper- 
ties of a nonpeptidic $\delta$ opioid receptor agonist, (-)TAN-67, in the mouse spinal cord. J Pharmacol Exp Ther 280:600-605. Medline

van Rijn RM, Brissett DI, Whistler JL (2012) Emergence of functional spinal $\delta$ opioid receptors after chronic ethanol exposure. Biol Psychiatry 71:232 238. CrossRef Medline

Wang H, Wessendorf MW (2001) Equal proportions of small and large DRG neurons express opioid receptor mRNAs. J Comp Neurol 429:590600. CrossRef Medline

Wang HB, Zhao B, Zhong YQ, Li KC, Li ZY, Wang Q, Lu YJ, Zhang ZN, He SQ, Zheng HC, Wu SX, Hökfelt TG, Bao L, Zhang X (2010) Coexpression of $\delta$ - and $\mu$-opioid receptors in nociceptive sensory neurons. Proc Natl Acad Sci U S A 107:13117-13122. CrossRef Medline

Woodbury CJ, Zwick M, Wang S, Lawson JJ, Caterina MJ, Koltzenburg M, Albers KM, Koerber HR, Davis BM (2004) Nociceptors lacking TRPV1 and TRPV2 have normal heat responses. J Neurosci 24:64106415. CrossRef Medline

Yu L, Yang F, Luo H, Liu FY, Han JS, Xing GG, Wan Y (2008) The role of TRPV1 in different subtypes of dorsal root ganglion neurons in rat chronic inflammatory nociception induced by complete Freund's adjuvant. Mol Pain 4:61. CrossRef Medline
Zachariou V, Goldstein BD (1996) $\delta$-Opioid receptor modulation of the release of substance P-like immunoreactivity in the dorsal horn of the rat following mechanical or thermal noxious stimulation. Brain Res 736:305-314. CrossRef Medline

Zhang G, Chen W, Marvizón JC (2010) Src family kinases mediate the inhibition of substance $\mathrm{P}$ release in the rat spinal cord by $\mu$-opioid receptors and $\mathrm{GABA}(\mathrm{B})$ receptors, but not $\alpha 2$ adrenergic receptors. Eur J Neurosci 32:963-973. CrossRef Medline

Zhang X, Bao L, Arvidsson U, Elde R, Hökfelt T (1998a) Localization and regulation of the $\delta$-opioid receptor in dorsal root ganglia and spinal cord of the rat and monkey: evidence for association with the membrane of large dense-core vesicles. Neuroscience 82:1225-1242. CrossRef Medline

Zhang X, Bao L, Shi TJ, Ju G, Elde R, Hokfelt T (1998b) Down-regulation of $\mu$-opioid receptors in rat and monkey dorsal root ganglion neurons and spinal cord after peripheral axotomy. Neuroscience 82:223-240. CrossRef Medline

Zwick M, Davis BM, Woodbury CJ, Burkett JN, Koerber HR, Simpson JF, Albers KM (2002) Glial cell line-derived neurotrophic factor is a survival factor for isolectin B4-positive, but not vanilloid receptor 1-positive, neurons in the mouse. J Neurosci 22:4057-4065. Medline 